\title{
Brain Dopamine Neurotoxicity in Baboons Treated with Doses of Methamphetamine Comparable to Those Recreationally Abused by Humans: Evidence from [ $\left.{ }^{11} \mathrm{C}\right] \mathrm{WIN}-35,428$ Positron Emission Tomography Studies and Direct In Vitro Determinations
}

\author{
Victor Villemagne, ${ }^{1}$ Jie Yuan, ${ }^{2}$ Dean F. Wong, ${ }^{1}$ Robert F. Dannals, ${ }^{1}$ George Hatzidimitriou, ${ }^{2}$ \\ William B. Mathews, ${ }^{1}$ Hayden T. Ravert, ${ }^{1}$ J. Musachio, ${ }^{1}$ Una D. McCann, ${ }^{3}$ and George A. Ricaurte ${ }^{2}$ \\ ${ }^{1}$ Department of Radiology, Division of Nuclear Medicine and 'Department of Neurology, The Johns Hopkins Medical \\ Institutions, Baltimore, Maryland 21205, and ${ }^{3}$ Unit on Anxiety Disorders, Biological Psychiatry Branch, National Institute of \\ Mental Health, Intramural Research Program, Bethesda, Maryland 20892
}

\begin{abstract}
The present study sought to determine whether doses of methamphetamine in the range of those used recreationally by humans produce brain dopamine (DA) neurotoxicity in baboons and to ascertain whether positron emission tomography (PET) imaging with the DA transporter (DAT) ligand $\left[{ }^{11} \mathrm{C}\right] \mathrm{WIN}-35,428$ ( $\left[{ }^{11} \mathrm{C}\right] 2 \beta$-carbomethoxy-3 $\beta$-(4-fluorophenyl)-tropane) could be used to detect methamphetamine-induced DAT loss in living primates. Baboons were treated with saline $(n=3)$ or one of three doses of methamphetamine $[0.5 \mathrm{mg} / \mathrm{kg}(n=2) ; 1 \mathrm{mg} / \mathrm{kg}$ $(n=2)$; and $2 \mathrm{mg} / \mathrm{kg}(n=3)$ ], each of which was given intramuscularly four times at $2 \mathrm{hr}$ intervals. PET studies were performed before and 2-3 weeks after methamphetamine treatment. After the final PET studies, animals were killed for direct neurochemical determination of brain DA axonal markers. PETderived binding potential values, used to index striatal DAT
\end{abstract}

density, were significantly decreased after methamphetamine, with larger decreases occurring after higher methamphetamine doses. Reductions in striatal DAT documented by PET were associated with decreases in DA, dihydroxyphenylacetic acid, and specific $\left[{ }^{3} \mathrm{H}\right] \mathrm{WIN}-35,428$ and $\left[{ }^{3} \mathrm{H}\right] \mathrm{DTBZ}$ binding determined in vitro. Decreases in DAT detected with PET were highly correlated with decreases in specific $\left[{ }^{3} \mathrm{H}\right] \mathrm{WIN}-35,428$ binding determined in vitro in the caudate of the same animal $(r=0.77$; $p=0.042)$. These results indicate that methamphetamine, at doses used by some humans, produces long-term reductions in brain DA axonal markers in baboons, and that it is possible to detect methamphetamine-induced DAT loss in living nonhuman primates by means of PET.

Key words: methamphetamine; dopamine; neurotoxicity; PET; primates; WIN-35,428
Methamphetamine, a potent psychomotor stimulant drug, is known on the street as "speed," "crystal meth," or "crank." Over the last 50 years, epidemics of methamphetamine abuse have occurred in many parts of the world, including Sweden (Inghe, 1969), the United Kingdom (Kiloh and Brandon, 1962), Japan (Brill and Hirose, 1969), and the United States (Kalant, 1966; Kramer et al., 1967; Miller and Hughes, 1994). To this day, abuse of methamphetamine continues, with recent surveys indicating that methamphetamine abuse is on the rise (Kozel, 1997; Lukas, 1997).

Methamphetamine is known to have the potential to damage brain dopamine (DA) and serotonin (5-HT) neurons. Laboratory animals given repeated high doses of methamphetamine show large, long-lasting depletions of brain DA and 5-HT (Kogan et al., 1976; Seiden et al., 1976; Hotchkiss and Gibb, 1980; Ricaurte et al., 1980; Wagner et al., 1980a,b; Slikker et al., 1988), as well as marked, long-term reductions in the activity of tyrosine hydroxylase and tryptophan hydroxylase (Hotchkiss et al., 1979; Hotchkiss and Gibb, 1980; Ricaurte et al., 1983; Schmidt et al.,

Received Aug. 21, 1997; revised Oct. 17, 1997; accepted Oct. 21, 1997.

This work was supported by Public Health Service Grants DA05707, DA06275 (G.A.R.), and DA09482 (D.F.W.). The technical support of Robert C. Smoot, David J. Clough, Karen Edmonds, and Paige Finley is gratefully acknowledged.

Correspondence should be addressed to Dr. George A. Ricaurte, Department of Neurology, The Johns Hopkins Medical Institutions, 5501 Bayview Drive, Room 5B71E, Baltimore, MD 21224.

Copyright (C) 1997 Society for Neuroscience $\quad 0270-6474 / 97 / 180419-\bullet \$ 05.00 / 0$
1985), the concentration of DA and 5-HT metabolites (Seiden et al., 1976; Hotchkiss and Gibb, 1980; Ricaurte et al., 1980), and the number of DA and 5-HT transporters (5-HTT) (Ricaurte et al., 1980; Wagner et al., 1980 a,b, 1982). Anatomic studies indicate that loss of these presynaptic DA and 5-HT axonal markers is related to damage of distal DA and 5-HT axon projections (Ellison, 1978; Lorez, 1981; Nwanze and Jonsson, 1981; Ricaurte et al., 1982, 1984a,b; Fukui et al., 1989; Axt et al., 1991). Methamphetamine neurotoxicity has been demonstrated in mice, rats, guinea pigs, cats, and rhesus monkeys (Seiden and Ricaurte, 1987). Moreover, the toxic effects of methamphetamine on brain DA and 5-HT neurons in nonhuman primates persist for up to 4 years (Woolverton et al., 1989), suggesting that they may be permanent, at least in rhesus monkeys given repeated high doses.

In all animal species tested, the neurotoxicity of methamphetamine is dose-dependent, generally occurring only after the administration of repeated high doses (Seiden and Ricaurte, 1987; Gibb et al., 1994). However, lower doses of methamphetamine or amphetamine can also produce neurotoxic effects, if administered continuously (via osmotic minipumps) (Ricaurte et al., 1984a,b), with iprindole (Fuller and Hemrick-Luecke, 1980; Peat et al., 1983), or at short time intervals (e.g., every 2 hr) (Sonsalla et al., 1989; Melega et al., 1993). Whether repeated doses of methamphetamine in the range of those used recreationally by humans [20-40 mg (Jaffe, 1985)] produce long-term effects on brain DA neurons in baboons is unknown. 
Although methamphetamine is a documented DA neurotoxin in animals, little is presently known regarding the DA neurotoxic potential of methamphetamine in humans, largely because of difficulties inherent in assessing DA neuronal integrity in the living human brain. Preclinical observations that amphetamines, if given repeatedly at short intervals (similar to the use pattern of "binge" methamphetamine users), can produce dopamine neurotoxicity (Sonsalla et al., 1989) suggest that human methamphetamine users may be at risk for methamphetamine-induced DA neural injury. The purpose of the present study was to determine whether methamphetamine, when given to baboons at a dose and in a pattern similar to that used by some humans [20-40 mg every 2-3 hr (Jaffe, 1985; Konuma, 1994)], produced long-term toxic effects on brain DA neurons. We also sought to determine whether PET imaging with $\left[{ }^{11} \mathrm{C}\right] \mathrm{WIN}-35,428$ could be used to detect methamphetamine-induced DAT loss in the brain of living nonhuman primates.

\section{MATERIALS AND METHODS}

Animals. Ten baboons (Papio anubis) were used in this study. Body weights ranged from 19 to $27 \mathrm{~kg}$. Ages of the animals could not be determined with certainty because the baboons were feral-reared. Animals were housed in a colony room maintained at $22 \pm 1^{\circ} \mathrm{C}$, with free access to food and water. The experimental protocol was approved by the Animal Care and Use Committee of the Johns Hopkins Medical Institutions.

Drug treatment. Animals were treated with three different doses $[0.5$ $\mathrm{mg} / \mathrm{kg}(n=2) ; 1 \mathrm{mg} / \mathrm{kg}(n=2) ;$ and $2 \mathrm{mg} / \mathrm{kg}(n=3)]$ of D-methamphetamine hydrochloride, with dose expressed as the salt Methamphetamine was dissolved in a sterile $0.9 \%$ sodium chloride solution and injected intramuscularly. Each dose of methamphetamine was given four times, at $2 \mathrm{hr}$ intervals, such that the total dose for each set of animals was 2,4 , and $8 \mathrm{mg} \cdot \mathrm{kg}^{-1} \cdot \mathrm{d}^{-1}$, respectively. This particular regimen of methamphetamine administration was used because it is known to produce long-term effects on brain DA neurons in rodents (Sonsalla et al., 1989), and $2 \mathrm{mg} / \mathrm{kg}$ doses of amphetamine given according to a similar regimen produce long-term DA deficits in green vervet monkeys (Melega et al., 1993). Also, such a dose regimen closely approximates the binge use of methamphetamine by some humans [20-40 mg every 2-3 hr (Jaffe, 1985; Konuma, 1994)].

Study design. Ten baboons were studied, using a design that permitted both between- and within-subject comparisons. Methamphetaminetreated baboons were studied with PET before, and 2-3 weeks after, drug treatment. Control baboons also underwent repeat PET scans before and after saline treatment to establish test-retest reproducibility. On completion of the final PET studies, animals were killed by an overdose of pentobarbital $(60 \mathrm{mg} / \mathrm{kg})$, and the brains were removed for neurochemical studies. Tissues for neurochemical studies were kept frozen in liquid nitrogen; control and experimental samples were assayed in parallel.

Preparation of $\left[{ }^{11} \mathrm{C}\right] W I N-35,428$. $\left[{ }^{11} \mathrm{C}\right] \mathrm{W}$ IN-35,428 was synthesized as described previously (Dannals et al., 1993). The average specific activity of the final product calculated at the end of synthesis was $>2000$ $\mathrm{mCi} / \mu \mathrm{mol}$.

PET imaging. On the day of the PET study, two intravenous catheters and an arterial catheter were placed for infusion of anesthesia, injection of radiotracer, and arterial blood sampling, respectively. Animals were initially anesthetized intramuscularly with $8-10 \mathrm{mg} / \mathrm{kg}$ alfadolone and alfaxolone acetate (Saffan) and intubated. Anesthesia was maintained throughout the study by a continuous intravenous infusion drip of 6-9 $\mathrm{mg} \cdot \mathrm{kg}^{-1} \cdot \mathrm{hr}^{[\mathrm{minus}[1]}$ alfadolone and alfaxolone acetate. The baboon was secured to the PET bed using an individually fitted thermoplastic mask, which allowed reproducible positioning between studies. Pulse, blood pressure, and oxygen saturation were monitored continuously during the studies. Blood oxygen saturation was always maintained above $85 \%$. After baboons were positioned in the PET scanner, a transmission scan was performed with a $10 \mathrm{mCi}{ }^{68} \mathrm{Ga}$ source to allow for attenuation correction. PET scanning was started immediately after intravenous injection of $20 \mathrm{mCi}$ of high specific activity [ $\left.{ }^{11} \mathrm{C}\right] \mathrm{WIN}-35,428$ (corresponding to $0.12 \mathrm{nmol} / \mathrm{kg}$ ). Fifteen simultaneous (eight direct planes, seven cross planes, $z$ axis $=\sim 10 \mathrm{~cm}$ ) sequential quantitative tomographic slices of the brain were obtained with the GE 4096+ PET tomograph in the high-resolution mode ( $\sim 6.5 \mathrm{~mm}$ full width at half maximum), over a $90 \mathrm{~min}$ period. Baboons were positioned so that the lowest plane was located approximately $5 \mathrm{~cm}$ below the canthomeatal line. Plasma radioactivity was corrected for decay and metabolites. In all cases, $\sim 30$ arterial samples/PET study (for radioassay and protein binding) were obtained over $90 \mathrm{~min}$. To correct the input function for unmetabolized $\left[{ }^{11} \mathrm{C}\right] \mathrm{WIN}-$ 35,428 , arterial samples were also obtained at 10, 20,30, 60, and $75 \mathrm{~min}$ after the injection of the radiotracer for analysis by means of high performance liquid chromatography (HPLC). PET images were reconstructed from the raw data with a standard filtered back-projection algorithm and a Hann filter $(6.0 \mathrm{~mm})$. Images were corrected for attenuation and decay. Regions of interest were placed manually over the striatum and the cerebellum, and time-activity curves were generated.

Postmortem monoamine and metabolite level determinations. Levels of monoamines and their major metabolites were determined by means of HPLC coupled with electrochemical detection (HPLC-EC), as described previously (Ricaurte et al., 1992).

In vitro $\left[{ }^{3} \mathrm{H}\right] W I N-35,428$ binding studies. $\left[{ }^{3} \mathrm{H}\right] \mathrm{W}$ IN-35,428-labeled DATs were measured using the method of Madras and colleagues (1989), with minor modification. Briefly, frozen striatal tissue was weighed, homogenized in $20 \mathrm{vol}(\mathrm{w} / \mathrm{v})$ of a $0.32 \mathrm{M}$ sucrose phosphate buffer, $\mathrm{pH} 7.4$, at $0-4^{\circ} \mathrm{C}$, and centrifuged at $\sim 45,000 \times g$ for $15 \mathrm{~min}$ at $0-4^{\circ} \mathrm{C}$. The supernatant was discarded, and the pellet was resuspended in $20 \mathrm{vol}$ of sucrose $\mathrm{PO}_{4}$ buffer and then centrifuged once again at $\sim 45,000 \times g$ for $15 \mathrm{~min}$ at $0-4^{\circ} \mathrm{C}$. The resulting pellet was suspended in buffer for a final tissue concentration of $10 \mathrm{mg} / \mathrm{ml}$ wet weight. $\left[{ }^{3} \mathrm{H}\right] \mathrm{W}$ IN-35,428 was used at a predetermined saturating concentration of $30 \mathrm{~nm}$. Cocaine, at a final concentration of $30 \mu \mathrm{M}$, was used to displace specific [ ${ }^{3} \mathrm{H}$ ]W IN-35,428 binding and estimate nonspecific binding. Tubes were incubated in sextuplicate for $60 \mathrm{~min}$, at $0-4^{\circ} \mathrm{C}$. Membranes were harvested by filtration through Whatman GFB filters soaked in $0.05 \%$ polyethyleneimine (PEI). Filters were washed three times using ice-cold sucrose $\mathrm{PO}_{4}$ buffer. Radioactivity was measured with a Packard-1500 Tricarb Liquid Scintillation Analyzer. Specific $\left[{ }^{3} \mathrm{H}\right]$ WIN35,428 binding was calculated by subtracting the average value of the six tubes containing excess cocaine from the average of the six tubes without cocaine. Specific $\left[{ }^{3} \mathrm{H}\right] \mathrm{WIN}-$ 35,428 binding was expressed in $\mathrm{dpm} / \mathrm{mg}$ original wet weight tissue. Nonspecific binding represented $\sim 7-10 \%$ of the total binding.

In vitro $\left[{ }^{3} \mathrm{H}\right]$ dihydrotetrabenazine (TBNZ) binding studies. $\left[{ }^{3} \mathrm{H}\right] \mathrm{DTBZ}$ binding, used to label type 2 vesicular monoamine transporter (VMAT) sites (Naudon et al., 1994; Vander Borght et al., 1996), was measured using the method of Wilson et al. (1996b), with minor modifications. Briefly, tissue samples were homogenized for $15 \mathrm{sec}$ in $20 \mathrm{vol}(\mathrm{w} / \mathrm{v})$ of sodium phosphate buffer $(25 \mathrm{~mm}, \mathrm{pH} 7.7)$ and then centrifuged in a Sorvall RC2B at $\sim 45,000 \times g$ for $15 \mathrm{~min}$ at $0-4^{\circ} \mathrm{C}$. The resulting pellet was resuspended in $20 \mathrm{vol}(\mathrm{w} / \mathrm{v})$ of sodium phosphate buffer, homogenized again for $15 \mathrm{sec}$, and recentrifuged at $\sim 45,000 \times g$ for $15 \mathrm{~min}$ at $0-4^{\circ} \mathrm{C}$. The supernatant was discarded, and the resulting pellet was resuspended in buffer at a final concentration of $10 \mathrm{mg}$ of original wet weight tissue per milliliter. Membrane preparations were incubated with a predetermined saturating concentration of $\left[{ }^{3} \mathrm{H}\right] \mathrm{DTBZ}(15 \mathrm{nM})$ in 25 mM sodium phosphate buffer, $\mathrm{pH} 7.7$, for $90 \mathrm{~min}$ at $30^{\circ} \mathrm{C}$ in a shaking water bath. Each sample was run in sextuplicate, such that six tubes were used to define total binding and six tubes were used to determine nonspecific binding. Nonspecific binding was determined in the presence of $1 \mu \mathrm{M}$ tetrabenazine and represented $\sim 8-10 \%$ of total binding. The incubation was terminated by rapid filtration, using a 48-well cell harvester (Brandell, Gaithersburg, MD) and Whatman GFB filters soaked with $0.05 \%$ PEI. Filters were washed three times with $10 \mathrm{ml}$ sodium phosphate buffer, and residual radioactivity was measured using a Packard-1500 Tricarb Liquid Scintillation Analyzer. Specific binding, calculated by subtracting nonspecific binding from total binding, was expressed as $\mathrm{dpm} / \mathrm{mg}$ original wet weight tissue.

In vitro $\left[{ }^{3} \mathrm{H}\right]$ paroxetine binding studies. $\left[{ }^{3} \mathrm{H}\right]$ paroxetine-labeled 5 -HTT were measured using the method of Habert et al. (1985), with the previously described minor modifications (Ricaurte et al., 1992).

In vitro $\left[{ }^{3} \mathrm{H}\right]$ nisoxetine binding studies. $\left[{ }^{3} \mathrm{H}\right]$ nisoxetine-labeled norepinephrine transporters (NETs) in tissue homogenates were measured using the method of Tejani-Butt (1992).

Autoradiographic studies. Autoradiograms with $\left[{ }^{3} \mathrm{H}\right] \mathrm{W}$ IN-35,428 ([ $\left.{ }^{3} \mathrm{H}\right]$-2 $\beta$-carbomethoxy-3 $\beta$-(4-fluorophenyl)-tropane) were prepared according to the method of Kaufman et al.(1991). [ $\left.{ }^{3} \mathrm{H}\right] \mathrm{W}$ IN-35,428 was used at a concentration of $3 \mathrm{~nm}$ to measure total binding and along with $30 \mu \mathrm{M}$ cocaine to determine nonspecific binding. Autoradiograms with $\left[{ }^{3} \mathrm{H}\right]$ mazindol were prepared using the method of Javitch et al. (1985). 


\section{[11 C] -WIN 35,428 Labeled DAT}

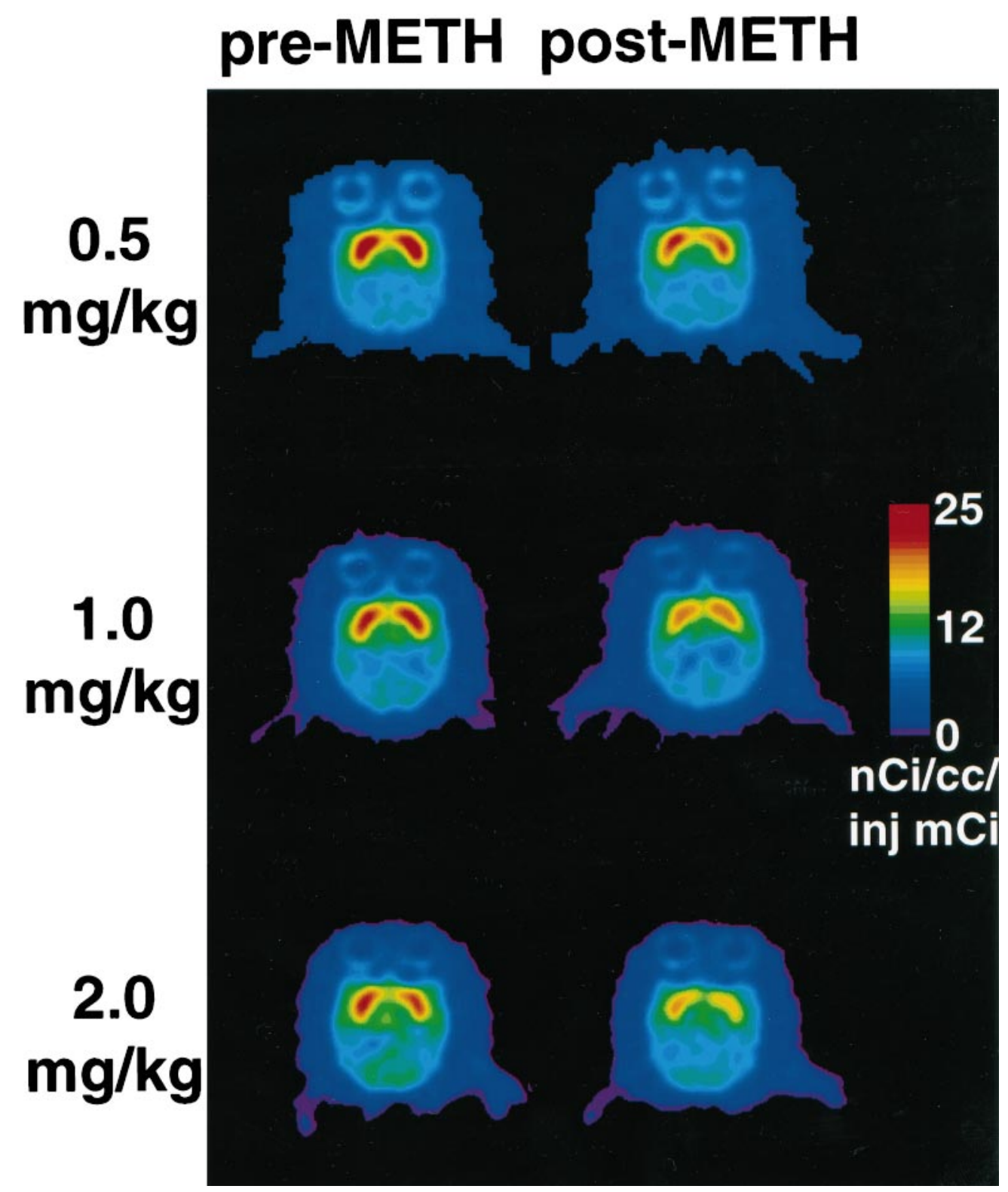

Figure 1. $\left[{ }^{11} \mathrm{C}\right] \mathrm{W}$ IN-35,428 images in baboons before (left) and 2-3 weeks after (right) treatment with three different doses of methamphetamine. Each dose was given four times, at $2 \mathrm{hr}$ intervals. Images shown are at midstriatal level from representative baboons. Images shown represent average PET images (between 70 and 90 min after injection of the radiotracer) normalized to injected activity.

$\left[{ }^{3} \mathrm{H}\right]$ mazindol was used at a concentration of $4 \mathrm{~nm}$ to measure total binding and along with $1 \mu \mathrm{M}$ mazindol to determine nonspecific binding.

Data analysis. PET data were analyzed by determining the binding potential (BP) (i.e., $B_{\max } / K_{\mathrm{d}}$ ), which represents the $\mathrm{k}_{3} / \mathrm{k}_{4}$ ratio of a threecompartment model described previously (Wong et al., 1993). In this approach, $\mathrm{K}_{1} / \mathrm{k}_{2}$ obtained in the cerebellum is used to constrain $\mathrm{K}_{1} / \mathrm{k}_{2}$ in the striatum, thereby reducing the number of parameters to 3 . For each animal, the DAT BP change induced by methamphetamine was determined by calculating the difference between the BP value obtained in the baseline study and the $\mathrm{BP}$ value obtained in the PET study after methamphetamine. The significance of differences observed was determined using a paired two-tailed $t$ test. Results from neurochemical studies were evaluated by ANOVA. When statistical differences were observed, post hoc comparisons were performed with Duncan's multiple range tests, compensating for multiple comparisons. Pearson product moment and Spearman's correlations were used to calculate the relation among the various DA axonal markers and imaging results, again compensating for multiple comparisons. All tests were two-tailed, and significance was set at $p \leq 0.05$. Data analysis was performed using the Statistical Program for the Social Sciences (SPSS for Windows, Release 6).
Drugs and chemicals. Dopamine (DA) hydrochloride, 5-hydroxytryptamine (5-HT, serotonin) creatinine sulfate complex, and 5-hydroxyindole-3-acetic acid (dicyclohexylammonium salt) were purchased from Sigma (St. Louis, MO). Perchloric acid was purchased from J. T. Baker (Phillipsburg, NJ). $\left[{ }^{3} \mathrm{H}\right]$ WIN35,428 (specific activity, 83.5 $\mathrm{Ci} / \mathrm{mmol}$ ), $\left[{ }^{3} \mathrm{H}\right]$ paroxetine (specific activity, $17.1 \mathrm{Ci} / \mathrm{mmol}$ ), $\left[{ }^{3} \mathrm{H}\right]$ mazindol (specific activity, $24.0 \mathrm{Ci} / \mathrm{mmol}$ ), and $\left[{ }^{3} \mathrm{H}\right]$ nisoxetine (specific activity $74 \mathrm{Ci} / \mathrm{mmol}$ ) were purchased from New England Nuclear (Boston, MA). $\left[{ }^{3} \mathrm{H}\right] \mathrm{TBNZ}$ (specific activity, $150 \mathrm{Ci} / \mathrm{mmol}$ ) was obtained from Amersham Life Science (Buckinghamshire, England). D-methamphetamine hydrochloride was obtained from the National Institute on Drug Abuse (Rockville, MD).

\section{RESULTS}

\section{PET studies}

Assessment of test-retest variability in three untreated baboons, each of which was imaged twice with $\left[{ }^{11} \mathrm{C}\right] \mathrm{WIN}-35,428$ in a 


\begin{tabular}{|c|c|c|}
\hline & Before & After \\
\hline \multicolumn{3}{|c|}{ Control $1.54 \pm 0.22 ; n=10^{a}$} \\
\hline \multicolumn{3}{|c|}{ Methamphetamine } \\
\hline \multirow[t]{2}{*}{$0.5 \mathrm{mg} / \mathrm{kg}$} & 1.6 & 0.9 \\
\hline & 2.6 & 1.7 \\
\hline \multirow[t]{2}{*}{$1.0 \mathrm{mg} / \mathrm{kg}$} & 1.2 & 0.7 \\
\hline & 1.1 & 0.6 \\
\hline \multirow[t]{3}{*}{$2.0 \mathrm{mg} / \mathrm{kg}$} & 1.1 & 0.5 \\
\hline & 1.0 & 0.5 \\
\hline & 2.9 & 0.9 \\
\hline
\end{tabular}

$\overline{{ }^{a} \text { Based on PET imaging results of } 10 \text { untreated baboons, including the animals that }}$ subsequently received methamphetamine.

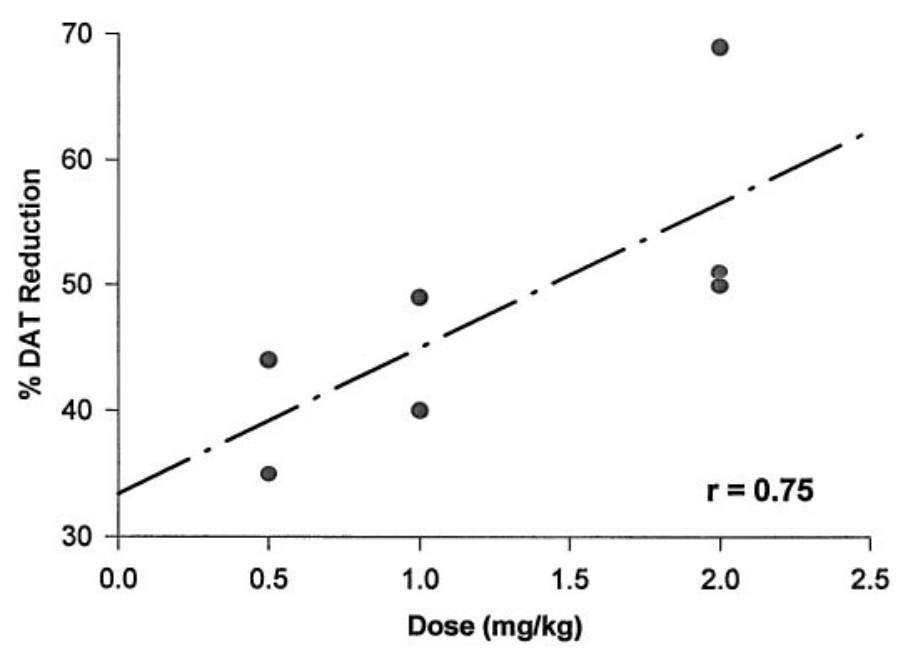

Figure 2. Relation between dose of methamphetamine and reduction in the DAT density, as measured by means of PET imaging with $\left[{ }^{11} \mathrm{C}\right] \mathrm{WIN}-$ 35,428. Methamphetamine was given intramuscularly at three different doses. Each dose was given four times, at $2 \mathrm{hr}$ intervals. Animals underwent PET studies 2-3 weeks after methamphetamine treatment.

manner identical to that of methamphetamine-treated animals, showed the mean $( \pm \mathrm{SD})$ percent variability to be $9.3 \pm 4.7 \%$.

The difference between pre- and postmethamphetamine PETderived $\left[{ }^{11} \mathrm{C}\right] \mathrm{WIN}-35,428 \mathrm{BP}$ values, used to index DAT density in vivo (Wong et al., 1993), was highly significant (mean $\pm \mathrm{SEM}$; paired difference: $0.82 \pm 0.21, t=3.84, p=0.009)$. Figure 1 shows the average PET images (between 70-90 min after injection of the radiotracer) normalized to injected activity from studies in three different baboons before and after treatment with methamphetamine at three different doses of methamphetamine $(0.5,1$, and $2 \mathrm{mg} / \mathrm{kg}$, respectively). BP reductions ranged from 35 to $44 \%$ at the $0.5 \mathrm{mg} / \mathrm{kg}$ dose, 40 to $48 \%$ at the $1 \mathrm{mg} / \mathrm{kg}$ dose, and 50 to $69 \%$ at the $2 \mathrm{mg} / \mathrm{kg}$ dose of methamphetamine (Table 1).

The linear correlation coefficient between BP reduction and methamphetamine dose was $r=0.75(p=0.05)$, with a Spearman correlation coefficient of 0.87 ( $p=0.01)$ (Fig. 2).

\section{Postmortem neurochemical studies}

Tables 2 and 3 show the results of postmortem neurochemical studies performed using tissue samples from the caudate and putamen of the same baboons that had undergone PET studies. Methamphetamine significantly reduced DA axonal markers in the caudate in a dose-dependent manner (Table 1), with larger dopaminergic deficits resulting from higher methamphetamine doses $\left(\mathrm{DA}: F_{(3,6)}=4.91, p=0.047\right.$; DOPAC: $F_{(3,6)}=5.95, p=$ 0.031; $\left[{ }^{3} \mathrm{H}\right]$ WIN-35,428 binding: $F_{(3,6)}=36.3, p<0.001$; $\left.\left[{ }^{3} \mathrm{H}\right] \mathrm{DTBZ}: F_{(3,6)}=16.7, p=0.002\right)$. Similar results were obtained in the putamen (Table 3 ), again with larger dopaminergic deficits resulting from higher methamphetamine doses (DA: $F_{(3,6)}$ $=9.15, p=0.012$; DOPAC: $F_{(3,6)}=4.93, p=0.046 ;\left[{ }^{3} \mathrm{H}\right] \mathrm{WIN}-$ 35,428 binding: $F_{(3,6)}=10.0, p=0.009 ;\left[{ }^{3} \mathrm{H}\right] \mathrm{DTBZ}: F_{(3,6)}=5.3$, $p=0.01)$.

The linear correlation coefficient between the reductions in striatal $\left[{ }^{11} \mathrm{C}\right] \mathrm{WIN}-35,428$-labeled DAT detected by means of PET in vivo and the decreases in $\left[{ }^{3} \mathrm{H}\right] \mathrm{WIN}-35,428$ binding determined in vitro in caudate homogenates of the same animals was $r=0.77(p=0.042)$, with a Spearman correlation coefficient of $0.90(p=0.006)$ (Fig. 3). In the putamen, the correlation did not achieve significance $(r=0.54, p=0.21)$. Figure 3 illustrates the reduction in striatal DAT density, as shown by coronal PET images of $\left[{ }^{11} \mathrm{C}\right] \mathrm{WIN}-35,428$ binding in living animals (top) and by autoradiography using $\left[{ }^{3} \mathrm{H}\right] \mathrm{WIN}-35,428$ (middle) and $\left[{ }^{3} \mathrm{H}\right]$ mazindol in postmortem tissue of the same animal (bottom).

Despite the relatively small sample size, correlational analyses were conducted to assess the relation among different DA axonal markers (DA, DOPAC, $\left[{ }^{3} \mathrm{H}\right] \mathrm{WIN}-35,428$, and $\left[{ }^{3} \mathrm{H}\right] \mathrm{DTBZ}$ ) in both the caudate and putamen of control and methamphetaminetreated baboons. In control caudate, statistically significant Pearson correlations $(p<0.05)$ were limited to DA versus DOPAC $(r=0.99)$; in control putamen, no significant correlations were observed. After methamphetamine, all DA axonal markers in the caudate were significantly intercorrelated $[r=0.87$ to $r=0.95$ except DA and $\left[{ }^{3} \mathrm{H}\right] \mathrm{DTBZ}(r=0.74, p=0.056)$, DOPAC and $\left[{ }^{3} \mathrm{H}\right] \mathrm{WIN}-35,428(r=0.72, p=0.065)$, and $\left[{ }^{3} \mathrm{H}\right] \mathrm{WIN}-35,428$ and $\left.\left[{ }^{3} \mathrm{H}\right] \mathrm{DTBZ}(r=0.68, p=0.094)\right]$. In the putamen of methamphetamine-treated animals, only $\left[{ }^{3} \mathrm{H}\right] \mathrm{WIN}-35,428$ and $\left[{ }^{3} \mathrm{H}\right] \mathrm{DTBZ}$ were significantly correlated $(r=0.92, p=0.003)$.

Methamphetamine also significantly reduced 5-HT axonal markers in the caudate in a dose-dependent manner (Table 2), with higher doses producing larger serotonergic deficits (5-HT: $F_{(3,6)}=4.78, p=0.049$; 5-HIAA: $\left.F_{(3,6)}=6.78, p=0.023\right)$. In the putamen, methamphetamine-induced 5-HT deficits did not achieve statistical significance $(p=0.12)$ (Table 3). By contrast, methamphetamine-induced 5-HIAA deficits in the putamen were significant, with higher doses producing larger serotonergic deficits $\left(F_{(3,6)}=5.42, p=0.038\right)$.

Methamphetamine also produced long-term reductions in regional cortical 5-HT, but not NE, axonal markers (Tables 4 and 5).

\section{DISCUSSION}

The results of the present study indicate that doses of methamphetamine on the order of those used recreationally by some humans (see below) produce lasting effects on brain DA axonal markers in baboons. Furthermore, the present results indicate that PET imaging with $\left[{ }^{11} \mathrm{C}\right] \mathrm{WIN}-35,428$ is suitable for detecting partial methamphetamine-induced reductions in brain DAT in living nonhuman primates. Together, these findings suggest that PET imaging with $\left[{ }^{11} \mathrm{C}\right] \mathrm{W}$ IN-35,428 will be useful for evaluating humans for possible methamphetamine-induced DA neurotoxicity, and they raise further concerns about the neurotoxic potential of methamphetamine in humans.

Surprisingly, methamphetamine produced long-term decreases on brain DA axonal markers in baboons at all doses tested, including the $0.5 \mathrm{mg} / \mathrm{kg}$ dose (Fig. 1, Tables 1-3). These results confirm and extend those of Melega and colleagues (1993) who 
Table 2. Monoaminergic neuronal markers in control and methamphetamine-treated baboons

\begin{tabular}{|c|c|c|c|c|c|c|}
\hline & \multicolumn{6}{|l|}{ Caudate } \\
\hline & DA & DOPAC & {$\left[{ }^{3} \mathrm{H}\right] \mathrm{WIN}$} & {$\left[{ }^{3} \mathrm{H}\right] \mathrm{DTBZ}$} & $5-\mathrm{HT}$ & 5-HIAA \\
\hline Control $(n=3)$ & $7.34 \pm 0.80$ & $0.52 \pm 0.05$ & $1695 \pm 173$ & $2541 \pm 108$ & $0.53 \pm 0.07$ & $0.44 \pm 0.04$ \\
\hline \multicolumn{7}{|c|}{ Methamphetamine } \\
\hline \multirow[t]{2}{*}{$0.5 \mathrm{mg} / \mathrm{kg}$} & $5.23(-29)$ & $0.38(-27)$ & $830(-51)$ & $2237(-12)$ & $0.25(-53)$ & $0.34(-23)$ \\
\hline & $5.36(-27)$ & $0.36(-31)$ & $1150(-32)$ & $2037(-20)$ & $0.49(-05)$ & $0.28(-36)$ \\
\hline \multirow[t]{2}{*}{$1.0 \mathrm{mg} / \mathrm{kg}$} & $2.99(-59)$ & $0.27(-48)$ & $819(-52)$ & $1091(-57)$ & $0.30(-43)$ & $0.40(-09)$ \\
\hline & $5.12(-30)$ & $0.40(-23)$ & $674(-60)$ & $1289(-49)$ & $0.26(-51)$ & $0.29(-34)$ \\
\hline \multirow[t]{3}{*}{$2.0 \mathrm{mg} / \mathrm{kg}$} & $2.73(-63)$ & $0.28(-46)$ & $543(-68)$ & $836(-67)$ & $0.05(-91)$ & $0.11(-75)$ \\
\hline & $1.93(-74)$ & $0.26(-50)$ & $512(-70)$ & $1097(-57)$ & $0.13(-75)$ & $0.21(-48)$ \\
\hline & $3.10(-58)$ & $0.31(-40)$ & $546(-68)$ & $1638(-35)$ & $0.26(-51)$ & $0.21(-48)$ \\
\hline
\end{tabular}






tissue. Values for each methamphetamine-treated baboon are provided, with the percentage change shown in parentheses.

Table 3. Monoaminergic neuronal markers in control and methamphetamine-treated baboons

\begin{tabular}{|c|c|c|c|c|c|c|}
\hline & \multicolumn{6}{|l|}{ Putamen } \\
\hline & DA & DOPAC & {$\left[{ }^{3} \mathrm{H}\right] \mathrm{WIN}$} & {$\left[{ }^{3} \mathrm{H}\right] \mathrm{DTBZ}$} & 5-HT & 5-HIAA \\
\hline Control $(n=3)$ & $8.13 \pm 0.79$ & $0.85 \pm 0.11$ & $2451 \pm 362$ & $3700 \pm 575$ & $0.32 \pm 0.05$ & $0.60 \pm 0.07$ \\
\hline \multicolumn{7}{|l|}{ Methamphetamine } \\
\hline \multirow[t]{2}{*}{$0.5 \mathrm{mg} / \mathrm{kg}$} & $5.43(-33)$ & $0.68(-20)$ & $1224(-50)$ & $2705(-27)$ & $0.23(-28)$ & $0.49(-18)$ \\
\hline & $4.67(-42)$ & $0.47(-45)$ & $1471(-40)$ & $2704(-27)$ & $0.30(-06)$ & $0.53(-12)$ \\
\hline \multirow[t]{2}{*}{$1.0 \mathrm{mg} / \mathrm{kg}$} & $4.10(-50)$ & $0.40(-53)$ & $986(-60)$ & $2040(-45)$ & $0.24(-25)$ & $0.42(-30)$ \\
\hline & $4.43(-45)$ & $0.47(-45)$ & $799(-67)$ & $1957(-47)$ & $0.18(-44)$ & $0.53(-12)$ \\
\hline \multirow[t]{3}{*}{$2.0 \mathrm{mg} / \mathrm{kg}$} & $4.60(-43)$ & $0.28(-67)$ & $483(-80)$ & $1126(-70)$ & $0.04(-88)$ & $0.22(-63)$ \\
\hline & $1.79(-78)$ & $0.56(-34)$ & $651(-73)$ & $1516(-59)$ & $0.10(-69)$ & $0.24(-60)$ \\
\hline & $3.74(-54)$ & $0.31(-64)$ & $1082(-56)$ & $2797(-24)$ & $0.21(-34)$ & $0.35(-42)$ \\
\hline
\end{tabular}

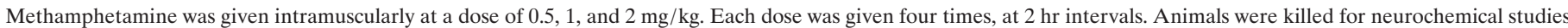

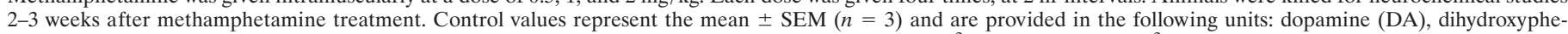

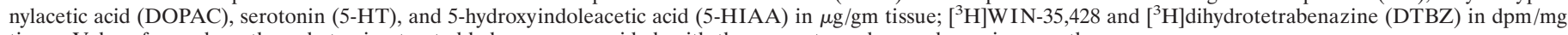
tissue. Values for each methamphetamine-treated baboon are provided, with the percentage change shown in parentheses.

observed decreases in 6-[ $\left.{ }^{18} \mathrm{~F}\right]$ fluoro-DOPA uptake in vervet monkeys injected with $4 \mathrm{mg} / \mathrm{kg}$ amphetamine (two injections of 2 $\mathrm{mg} / \mathrm{kg}$, i.m.) 1 week and 1 month previously. Using interspecies scaling methods (Harwood, 1963; Mordenti and Chappell, 1989; Chappell and Mordenti, 1991), it is possible to estimate equivalent doses in humans by taking into account known relationships between body mass and surface area. When this is done for the two lower doses of methamphetamine used in the present study ( 0.5 and $1 \mathrm{mg} / \mathrm{kg}$ ), the equivalent human doses (for an individual weighing $70 \mathrm{~kg}$ ) are 26 and $52 \mathrm{mg}$, respectively. These doses are well within the range of those reported to be used by human methamphetamine users on a repeated basis (Jaffe, 1985; Konuma, 1994), particularly after tolerance has developed (Kalant, 1966; Kramer et al., 1967; Lukas, 1997). The notion that only extraordinarily high doses of methamphetamine can produce DA neurotoxicity needs to be reconsidered, at least in primates exposed to repeated doses of methamphetamine.

As mentioned above, if methamphetamine-induced DAT loss occurs in humans, PET imaging with $\left[{ }^{11} \mathrm{C}\right] \mathrm{WIN}-35,428$ should prove useful for its detection. Baboons with known methamphetamine-induced DAT loss show clear evidence of decreased striatal DAT density (Fig. 1, Table 1). Moreover, there is an excellent correlation between decreased striatal DAT density, as measured by PET, and decreases in specific $\left[{ }^{3} \mathrm{H}\right] \mathrm{WIN}$ 35,428 binding determined in vitro in the caudate of the same animal $(r=0.77, p=0.042)$. The fact that reductions in striatal DAT in methamphetamine-treated baboons are associated with comparable decreases in other markers of DA axon terminals (Tables 2, 3) suggests that PET imaging with $\left[{ }^{11} \mathrm{C}\right] \mathrm{WIN}-35,428$ will be useful for detecting methamphetamine-induced DA neurotoxicity in humans, if it occurs.

Recently, Wilson and colleagues (1996a) examined striatal DA nerve terminal markers in postmortem tissue from humans with a history of chronic methamphetamine abuse and found reduced levels of DA, tyrosine hydroxylase (TH), and DAT, but normal levels of DOPAC, aromatic amino acid decarboxylase (AADC), and the VMAT. On the basis of these findings, Wilson et al. (1996a) concluded that chronic exposure to methamphetamine did not cause permanent degeneration of striatal dopamine nerve terminals in the subjects in their study. In large part, these investigators based their conclusion on the fact that in patients with Parkinson's disease, in whom striatal dopamine nerve terminal degeneration is well documented (Hornykiewicz, 1966), not only are the levels of DA, TH, and DAT reduced but so are the levels of DOPAC, AADC, and VMAT (Wilson et al., 1996b). The basis for apparent differences between methamphetaminetreated baboons in the present study and chronic methamphetamine users in the study by Wilson and colleagues (1996a) is not certain but could possibly be related to differences in drug use patterns (e.g., it is possible that none of the methamphetamine 


\section{Control METH}

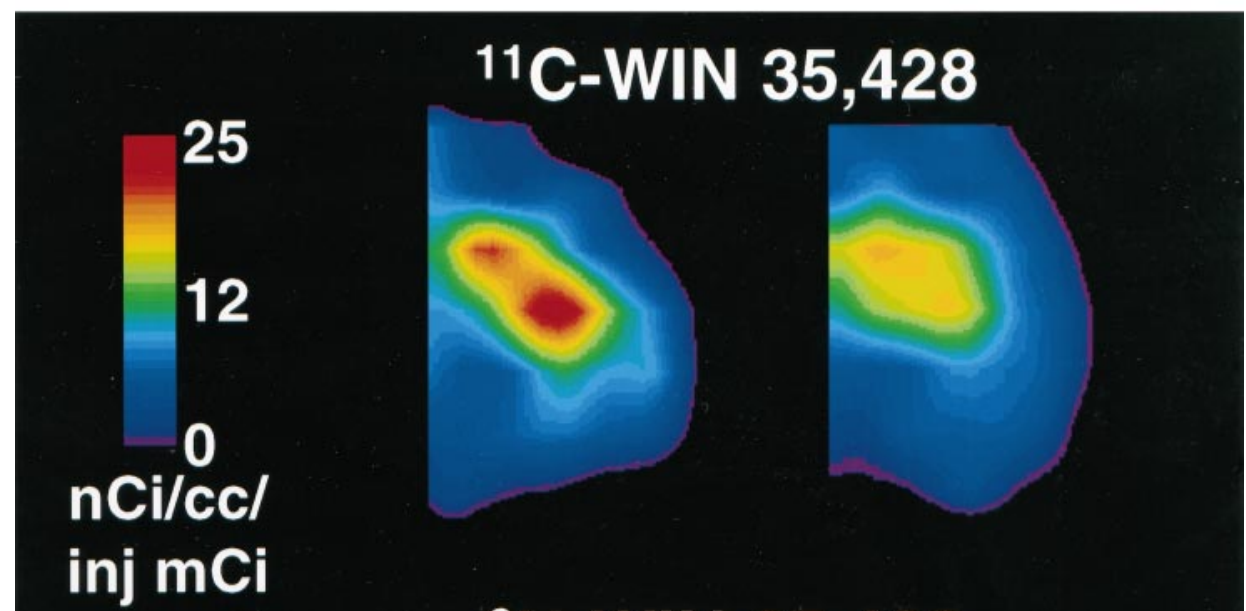

5.0

\section{${ }^{3} \mathrm{H}-$ WIN 35,428}

Figure 3. Reductions in striatal DAT density, as shown by coronal PET images of $\left[{ }^{11} \mathrm{C}\right] \mathrm{W}$ IN-35,428 binding in living animal (top) and autoradiography using $\left[{ }^{3} \mathrm{H}\right] \mathrm{W}$ IN35,428 (middle) and $\left[{ }^{3} \mathrm{H}\right]$ mazindol (bottom) in postmortem tissue of the same animal. Methamphetamine $(2 \mathrm{mg} / \mathrm{kg})$ was given four times, at $2 \mathrm{hr}$ intervals. $\left[{ }^{11} \mathrm{C}\right] \mathrm{WIN}$ 35,428 binding was reduced by $69 \%$ (control BP value: 2.99; methamphetamine: 0.93), $\left[{ }^{3} \mathrm{H}\right] \mathrm{W}$ IN-35,428 was reduced by $75 \%$ (control: $2.7 \mathrm{nCi} / \mathrm{mg}$; methamphetamine: 0.7 $\mathrm{nCi} / \mathrm{mg}$ ), and $\left[{ }^{3} \mathrm{H}\right]$ mazindol was reduced by 68\% (control: $4.3 \mathrm{nCi} / \mathrm{mg}$; methamphetamine: $1.4 \mathrm{nCi} / \mathrm{mg}$ ). PET studies were performed 2-3 weeks after methamphetamine treatment. Tissue for autoradiographic studies was also obtained 2-3 weeks after methamphetamine treatment, shortly after PET studies were completed.

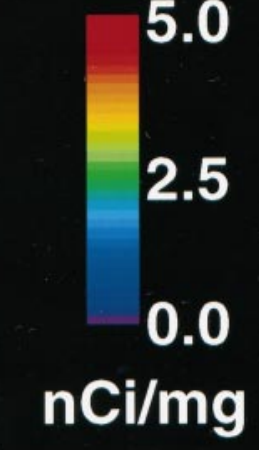

users engaged in binge methamphetamine use, a pattern that is more likely to produce neurotoxicity). It is also possible that nondopaminergic sources of VMAT and AADC (e.g., other monoaminergic neurons) in the chronic methamphetamine users masked DA-specific decreases of these enzymes. A third possible explanation for this apparent discrepancy could be that the neuropathology of Parkinson's disease is not identical to that of methamphetamine neurotoxicity, although the reductions in DOPAC and VMAT observed in methamphetamine-treated baboons (Tables 1,2$)$ suggest that there are similarities. Finally, the presence of residual drug (methamphetamine and amphetamine) in the human brain tissue samples analyzed by Wilson et al. (1996a) may complicate the interpretation of alterations of DA axonal markers, as could neuroadaptive processes involving the DA transporter. Clearly, additional studies are needed to deter- mine the DA neurotoxic potential of methamphetamine in humans.

The present findings are in good agreement with those of previous PET studies using other presynaptic DA neuroligands to assess the integrity of brain DA neurons after toxic drug exposure. For instance, using PET with 6- $\left[{ }^{18} \mathrm{~F}\right]$ fluoro-DOPA, Melega and colleagues (1996) have shown lasting decrements in striatal DA synthesis capacity in vervet monkeys treated with escalating doses of amphetamine. Similarly, using PET with 6- $\left[{ }^{18} \mathrm{~F}\right]$ fluoroDOPA, Calne and colleagues (1985) successfully detected dopaminergic deficits in young drug addicts who unwittingly experimented with 1-methyl-4-phenyl-1,2,3,6-tetrahydropyridine (MPTP), a potent dopaminergic neurotoxin (Langston, 1985). More recently, brain DA neural injury has also been detected with PET using $\left[{ }^{11} \mathrm{C}\right]$ - or $\left[{ }^{18} \mathrm{~F}\right]$-labeled radioligands that bind to 
Table 4. Regional cortical 5-HT and NE concentrations in control and methamphetamine-treated baboons

\begin{tabular}{|c|c|c|c|c|c|c|}
\hline & \multicolumn{2}{|l|}{ Frontal cortex } & \multicolumn{2}{|c|}{$\underline{\text { Parietal cortex }}$} & \multicolumn{2}{|c|}{ Temporal cortex } \\
\hline & 5-HT & $\mathrm{NE}$ & $5-\mathrm{HT}$ & $\mathrm{NE}$ & $5-\mathrm{HT}$ & $\mathrm{NE}$ \\
\hline Control $(n=3)$ & $101.1 \pm 16.8$ & $36.7 \pm 2.8$ & $95.1 \pm 4.6$ & $39.1 \pm 5.7$ & $175.0 \pm 5.5$ & $29.4 \pm 3.5$ \\
\hline Methamphetamine $(n=3)$ & $52.3 \pm 2.0^{a}$ & $31.2 \pm 2.5$ & $57.0 \pm 2.3^{a}$ & $42.6 \pm 6.1$ & $119.6 \pm 5.1^{a}$ & $22.3 \pm 3.1$ \\
\hline
\end{tabular}

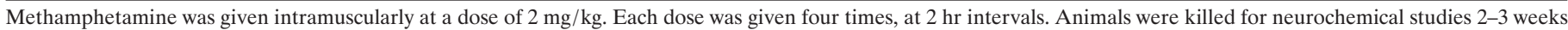
after methamphetamine treatment. Control values represent the mean $\pm \operatorname{SEM}(n=3)$. Values are in $\mu \mathrm{g} / \mathrm{mg}$ tissue.

${ }^{a}$ Designates significant difference from control $(p<0.05)$.

Table 5. Regional cortical 5-HT and NET densities in control and methamphetamine-treated baboons

\begin{tabular}{|c|c|c|c|c|c|c|}
\hline & \multicolumn{2}{|l|}{ Frontal cortex } & \multicolumn{2}{|c|}{ Parietal cortex } & \multicolumn{2}{|c|}{ Temporal cortex } \\
\hline & $\begin{array}{l}\text { 5-HT } \\
\text { transporter }\end{array}$ & $\begin{array}{l}\mathrm{NE} \\
\text { transporter }\end{array}$ & $\begin{array}{l}5-\mathrm{HT} \\
\text { transporter }\end{array}$ & $\begin{array}{l}\mathrm{NE} \\
\text { transporter }\end{array}$ & $\begin{array}{l}5-\mathrm{HT} \\
\text { transporter }\end{array}$ & $\begin{array}{l}\mathrm{NE} \\
\text { transporter }\end{array}$ \\
\hline Control $(n=3)$ & $772.2 \pm 74.4$ & $362.7 \pm 79.2$ & $396.1 \pm 68.3$ & $446.9 \pm 57.7$ & $921.0 \pm 75.8$ & $263.6 \pm 24.7$ \\
\hline Methamphetamine $(n=3)$ & $537.7 \pm 81.5^{a}$ & $345.9 \pm 54.3$ & $268.5 \pm 55.3$ & $464.5 \pm 37.0$ & $575.6 \pm 84.5^{a}$ & $268.6 \pm 30.3$ \\
\hline
\end{tabular}

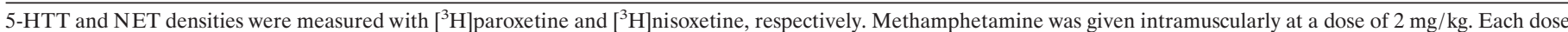

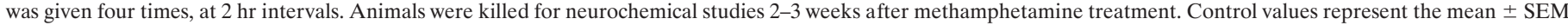
$(n=3)$. Values are in $\mu \mathrm{g} / \mathrm{mg}$ tissue.

${ }^{a}$ Designates significant difference from control $(p<0.05)$.

DA axonal markers, including $\left[{ }^{11} \mathrm{C}\right]$ nomifensine (Aquilonius et al., 1987, Leenders et al., 1988, Tedroff et al., 1988), $\left[{ }^{18} \mathrm{~F}\right] \mathrm{GBR}$ 13119 (Kilbourn et al., 1988, 1989a,b), $\left[{ }^{11}\right.$ C]DTBZ (Frey et al., 1996), $\left[{ }^{11} \mathrm{C}\right]$ cocaine (Fowler et al., 1989), and $\left[{ }^{11} \mathrm{C}\right] \mathrm{WIN}-35,428$ (Frost et al., 1993; Wong et al., 1993, 1996; Brownell et al., 1996; Morris et al., 1996), which is also known as $2 \beta$-carbomethoxy- $3 \beta$ (4-fluorophenyl)-[N-[ $\left.{ }^{11} \mathrm{C}\right]$ methyl $]$ tropane or $\left[{ }^{11} \mathrm{C}\right] \mathrm{CFT}$ (Madras et al., 1989; Canfield et al., 1990; Kaufman et al., 1991). Compared to 6- $\left[{ }^{18} \mathrm{~F}\right]$ fluoro-DOPA, DAT and VMAT ligands (Frey et al., 1996), may prove preferable for detecting neurotoxic injury (Nyhan and Wong, 1996), because they label "structural" macromolecular elements of the neuron rather than its transmitter precursor pool, which may be more amenable to metabolic perturbation.

As indicated in the introductory remarks, methamphetamine is toxic to both DA and 5-HT axon terminals, and 5-HT neuronal markers were found to be significantly decreased in methamphetamine-treated baboons in the present study. Hence, the question arises as to whether any of the long-term reductions in $\left[{ }^{11} \mathrm{C}\right] \mathrm{WIN}-35,428$ binding observed in methamphetaminetreated baboons might be attributable to loss of the 5-HTT. Previous in vitro studies indicate that although $\left[{ }^{11} \mathrm{C}\right] \mathrm{WIN}-35,428$ has high affinity for the DAT, it has much lower affinity for the 5-HTT (Madras et al., 1989; Canfield et al., 1990; Kaufman et al., 1991). Furthermore, in vivo studies have failed to reveal binding of $\left[{ }^{11} \mathrm{C}\right]$ WIN-35,428 to the 5-HTT (Scheffel et al., 1991). Thus, it seems unlikely that any of the observed reductions in $\left[{ }^{11} \mathrm{C}\right] \mathrm{WIN}$ 35,428 binding after methamphetamine treatment are caused by methamphetamine-induced loss of the 5-HTT.

The results of the present studies have basic and clinical relevance. Scientifically, it is important to determine whether studies of methamphetamine neurotoxicity in animals accurately predict possible long-term effects of methamphetamine in humans. In addition, if methamphetamine neurotoxicity is found to occur in humans, a better understanding of underlying mechanisms may provide insight into the basis for dopamine neuronal degeneration in Parkinson's disease and related neurodegenerative conditions (Fuller, 1992). Clinically, detection of possible DA neuro- toxicity in humans previously exposed to methamphetamine is important, because such individuals may have an increased risk for developing Parkinson's disease as they age (Calne and Langston, 1983; Calne et al., 1985), and they could be candidates for putative prophylactic pharmacotherapies such as deprenyl (Tetrud and Langston, 1989; The Parkinson Study Group, 1989, 1993).

In summary, the results of the present study indicate that doses of methamphetamine in the range of those used recreationally by some humans produce significant decrements in brain DA axonal markers in baboons, and that it is possible to detect lasting DAT loss in living nonhuman primates by means of PET. The fact that PET imaging with $\left[{ }^{11} \mathrm{C}\right] \mathrm{W}$ IN-35,428 can detect partial decrements in striatal DAT, decrements not associated with clinical signs of overt parkinsonism, is important because methamphetamine-induced reductions in DA axonal markers are typically in the range of $30-70 \%$ (depending on dose, species, brain region, and survival time) (Seiden and Ricaurte, 1987) and are not detectable clinically. Thus, if subclinical methamphetamine-induced DA neural injury in humans occurs, PET imaging with $\left[{ }^{11} \mathrm{C}\right] \mathrm{W}$ IN-35,428 should facilitate its detection and help define the health risks associated with the use and abuse of methamphetamine.

\section{REFERENCES}

Aquilonius SM, Bergstrom K, Eckernas SA, Hartvig P, Leenders KL, Lundquist H, Antoni G, Gee A, Rimoand A, Uhlin J, Langstrom B (1987) In vivo evaluation of striatal dopamine reuptake sites using $\left[{ }^{11} \mathrm{C}\right]$ nomifensine and positron emission tomography. Acta Neurol Scand 76:283-287.

Axt KJ, Molliver ME (1991) Immunocytochemical evidence for methamphetamine-induced serotonergic axon loss in the rat brain. Synapse 9:302-313.

Brill H, Hirose T (1969) The rise and fall of a methamphetamine epidemic: Japan 1945-1955. Semin Psychiatry 1:179-213.

Brownell AL, Elmaleh DR, Meltzer PC, Shoup TM, Brownell GL, Fischman AJ, Madras BK (1996) Cocaine congeners as PET imaging probes for dopamine terminals. J Nucl Med 37:1186-1192.

Calne DB, Langston JW (1983) On the etiology of Parkinson's disease. Lancet 2:1457-1459.

Calne DB, Langston JW, Martin W, Stoessel A, Ruth T, Adam M, 
Schulzer M (1985) Positron emission tomography after MPTP: observations relating to the cause of Parkinson's disease. Nature 317:246-248.

Canfield DR, Spealman RD, Kaufman MJ, Madras BK (1990) Autoradiographic localization of cocaine binding sites by $\left(\left[{ }^{3} \mathrm{H}\right] \mathrm{W}\right.$ IN-35,428) in the monkey brain. Synapse 6:189-195.

Chappell W, Mordenti J (1991) Extrapolation of toxicological and pharmacological data from animals to humans. In: Advances in drug research (Testa B, ed), pp 1-116. San Diego: Academic.

Dannals RF, Neumeyer JL, Milius RA, Ravert HT, Wilson AA, Wagner Jr HN (1993) Synthesis of a radiotracer for studying dopamine uptake sites in vivo using PET: 2b-carbomethoxy-3b-(4-fluorophenyl)- $\left[N-{ }^{11} \mathrm{C}\right.$ methyl]tropane $\left(\left[{ }^{11} \mathrm{C}\right] \mathrm{CFT}\right.$ or $\left.\left[{ }^{11} \mathrm{C}\right] \mathrm{WIN}-35,428\right)$. J Label Comp Radiopharmacol 33:147-152.

Ellison G, Elson MS, Huberman HS, Daniel F (1978) Long-term changes in dopaminergic innervation of caudate nucleus after continuous amphetamine administration. Science 201:276-278.

Fowler JS, Volkow ND, Wolf AP, Dewey SL, Schyler DJ, MacGregor RR, Hitzemann R, Logan J, Bendrienn B, Gately SJ, Christman D (1989) Mapping cocaine binding sites in human and baboon brain in vivo. Synapse 4:371-377.

Frey K, Koeppe R, Kilbourn M, Vander Borght T, Albin R, Gilman S, Kuhl D (1996) Presynaptic monoaminergic vesicles in Parkinson's disease and normal aging. Ann Neurol 40:873-884.

Frost JJ, Rosier AJ, Reich SG, Smith JS, Ehlers MD, Snyder SH, Ravert HT, Dannals RF (1993) Positron emission tomographic imaging of the dopamine transporter with ${ }^{11} \mathrm{C}-\mathrm{WIN}-35,428$ reveals marked declines in mild Parkinson's disease. Ann Neurol 34:423-431.

Fuller R, Hemrick-Luecke S (1980) Long-lasting depletion of striatal dopamine by a single injection of amphetamine in iprindole-treated rats. Science 209:305-307.

Fuller RW (1992) Comparison of MPTP and amphetamines as dopaminergic neurotoxins. Ann NY Acad Sci 648:87-95.

Fukui K, Nakajima T, Kariyama H, Kashiba A, Kato N, Tohyama I, Kimura H (1989) Selective reduction of serotonin immunoreactivity in some forebrain regions of rats induced by acute methamphetamine treatment: quantitative morphometric analysis by serotonin immunocytochemistry. Brain Res 482:198-203.

Gibb JW, Hanson, GR, Johnson M (1994) Neurochemical mechanisms of toxicity. In: Amphetamine and its analogs (Cho AK, Segal DS, eds), pp 269-295. San Diego: Academic.

Habert E, Graham G, Tahraoui L, Claustre Y, Langer SZ (1985) Characterization of $\left[{ }^{3} \mathrm{H}\right]$-paroxetine binding in rat cortical membranes. Eur J Pharmacol 118:107-114.

Harwood PD (1963) Therapeutic dosage in small and large mammals. Science 139:684-685.

Hornykkiewicz O (1966) Dopamine (3-hydroxytyramine) and brain function. Pharmacol Rev 18:925-965.

Hotchkiss AJ, Gibb JW (1980) Long-term effects of multiple doses of methamphetamine on tryptophan hydroxylase and tyrosine hydroxylase activity in rat brain. J Pharmacol Exp Ther 214:257-262.

Hotchkiss AJ, Morgan ME, Gibb JW (1979) The long-term effects of multiple doses of methamphetamine on neostriatal tryptophan hydroxylase, tyrosine hydroxylase, choline acetyltransferase and glutamate decarboxylase activities. Life Sci 25:1373-1378.

Inghe G (1969) The present state of abuse and addiction to stimulant drugs in Sweden. In: Abuse of central stimulants (Sjoqvist F, Tottie M, eds), pp 19-27. Stockholm: Almqvist and Wiksell.

Jaffe J (1985) Drug addiction and drug abuse (1985). In: Pharmacological basis of therapeutics (Goodman L, Gilman S, eds), pp 284-324. New York: McMillan.

Javitch J, Strittmatter S, Snyder S (1985) Differential visualization of dopamine and norepinephrine uptake sites in rat brain using $\left[{ }^{3} \mathrm{H}\right]$ mazindol autoradiography. J Neurosci 5:1513-1521.

Kalant O (1966) The amphetamines: toxicity and addiction (Thomas C, ed). Toronto: University of Toronto.

Kaufman MJ, Spealman RD, Madras BK (1991) Distribution of cocaine recognition sites in monkey brain. I. In vitro autoradiography with $\left[{ }^{3} \mathrm{H}\right] \mathrm{CFT}$. Synapse 9:177-187.

Kilbourn MR (1988) In vivo binding of $\left[{ }^{18} \mathrm{~F}\right] \mathrm{GBR} 13119$ to the brain dopamine uptake system. Life Sci 42:1347-1353.

Kilbourn MR, Carey JE, Koeppe RA, Haka MS, Hutchins GD, Sherman PS, Kuhl DE (1989a) Biodistribution, dosimetry, metabolism and monkey PET studies of $\left[{ }^{18} \mathrm{~F}\right] \mathrm{GBR}$ 13119: imaging the dopamine uptake system in vivo. Int J Radiat Appl Instrum [Part B] 16:569-576.
Kilbourn MR, Haka MS, Mulholland GK, Jewett DM, Kuhl DE (1989b) Synthesis of radiolabeled inhibitors of presynaptic monoamine uptake systems: fluorine-18 GBR-13119 DA, carbon-11 nisoxetine NE and carbon-11 fluoxetine 5-HT. J Label Comp Radiopharmacol 26:412-414.

Kiloh LG, Brandon S (1962) Habituation and addiction to amphetamines. Br Med J 40:3.

Kogan FJ, Nichols W K, Gibb JW (1976) Influence of methamphetamine on nigral and striatal tyrosine hydroxylase activity and on striatal dopamine levels. Eur J Pharmacol 36:363-371.

Konuma K (1994) Use and abuse of amphetamines in Japan. In: Amphetamine and its analogs (Cho AK, Segal DS, eds), pp 415-435. San Diego: Academic.

Kozel N (1997) Epidemiologic trends in drug abuse, Vol 1. National Institute on Drug Abuse, NIH Publication No. 97-4204.SS.

Kramer JC, Fischman VS, Littlefield DC (1967) Amphetamine abuse: pattern and effects of high doses taken intravenously. JAMA 210:305-309.

Langston JW (1985) MPTP and Parkinson's disease. Trends Neurosci 8:79-83

Leenders KL, Aquilonius SM, Bergstrom K, Bjurling P, Crossman AR, Eckernas SA, Gee AG, Hartvig P, Lundquist H, Langstrom B, Rimland A, Tedroff J (1988) Unilateral MPTP lesion in a rhesus monkey: effects on the striatal dopaminergic system measured in vivo with PET using various novel tracers. Brain Res 445:61-67.

Lorez H (1981) Fluorescence histochemistry indicates damage of striatal dopamine nerve terminals in rats after multiple doses of methamphetamine. Life Sci 28:911-916.

Lukas SE (1997) Proceedings of the National Consensus Meeting on the use, abuse and sequelae of abuse of methamphetamine with implications for prevention, treatment and research. DHHS Publication SMA 96-8013. Rockville, MD: USDHHS.

Madras BK, Spealman RD, Fahey MA, Neumeyer JL, Saha JK, Milius RA (1989) Cocaine receptors labeled by $\left[{ }^{3} \mathrm{H}\right]$-b-carbomethoxy-3- $\beta$ - $(4-$ fluorophenyl)-tropan. Mol Pharmacol 36:518-524.

Melega WP, Yu DC, Raleigh MJ, Huang SC, Phelps ME (1993) FDOPA-PET studies show neurotoxic effects of low-dose amphetamine in monkeys. Soc Neurosci Abstr 19:822.

Melega WP, Quintana J, Raleigh MJ, Stout DB, Yu DC, Lin KP, Huang SC, Phelps ME (1996) 6-[ ${ }^{18}$ F]fluoro-[sca]l-DOPA-PET studies show partial reversibility of long-term effects of chronic amphetamine in monkeys. Synapse 22:63-69.

Miller M, Hughes A (1994) Epidemiology of amphetamine abuse in the United States. In: Amphetamine and its analogs (Cho AK, Segal DS, eds), pp 439-457. San Diego: Academic.

Mordenti J, Chappell W (1989) The use of interspecies scaling in toxicokinetics. In: Toxicokinetics in new drug development (Yacobi A, Kelly J, Batra V, eds), pp 42-96. New York: Pergamon.

Morris ED, Babich JW, Alpert NM, Bonab AA, Livni E, Weise S, Hsu H, Christian BT, Madras BK, Fischman AJ (1996) Quantification of dopamine transporter density in monkeys by dynamic PET imaging of multiple injections of ${ }^{11} \mathrm{C}-\mathrm{CFT}$. Synapse 24:262-272.

Naudon L, Leroux-Nicollet I, Constentin J (1994) Short-term treatments with haloperidol or bromocryptine do not alter the density of the vesicular monoamine transporter. Neurosci Lett 173:1-4.

Nyhan WL, Wong DF (1996) New approaches to understanding LeschNyhan disease. N Engl J Med 334:1602-1604.

Nwanze F, Jonsson G (1981) Amphetamine neurotoxicity on dopamine nerve terminals in the caudate nucleus of mice. Neurosci Lett 26:163-168.

Peat MA, Warren PF, Gibb JW (1983) Effects of a single dose of methamphetamine and iprindole on the serotonergic and dopaminergic system of the rat brain. J Pharmacol Exp Ther 225:126-131.

Ricaurte GA, Schuster CR, Seiden LS (1980) Long-term effects of repeated methylamphetamine administration on dopamine and serotonin neurons in the rat brain: a regional study. Brain Res 193:153-163.

Ricaurte GA, Guillery RW, Seiden LS, Schuster CR, Moore RY (1982) Dopamine nerve terminal degeneration produced by high doses of methylamphetamine in the rat brain. Brain Res 235:93-103.

Ricaurte GA, Seiden LS, Schuster CR (1983) Increased dopamine metabolism in the rat neostriatum after toxic doses of D-methylamphetamine. Neuropharmacology 22:1383-1388.

Ricaurte GA, Guillery RW, Seiden LS, Schuster CR (1984a) Nerve terminal degeneration after a single injection of D-amphetamine in 
iprindole-treated rats: relation to selective long-lasting dopamine depletion. Brain Res 291:378-382.

Ricaurte GA, Seiden LS, Schuster CR (1984b) Further evidence that amphetamines produce long-lasting dopamine neurochemical deficits by destroying dopamine nerve fibers. Brain Res 303:359-364.

Ricaurte GA, Martello AL, Katz JL (1992) Lasting effects of MDMA on central serotonergic neurons in non-human primates: neurochemical observations. J Pharmacol Exp Ther 261:616-622.

Scheffel U, Pogun S, Stathis M, Boja J, Kuhar M (1991) In vivo labeling of cocaine binding sites on dopamine transporters with $\left[{ }^{3} \mathrm{H}\right] \mathrm{WIN}$ 35,428 J Pharmacol Exp Ther 257:954-958.

Schmidt CJ, Ritter JK, Sonsalla KP, Hanson GR, Gibb JW (1985) Role of dopamine in the neurotoxic effects of methamphetamine. J Pharmacol Exp Ther 233:539-543.

Seiden LS, Ricaurte GA (1987) Neurotoxicity of methamphetamine and related drugs. In: Psychopharmacology-a generation of progress (Meltzer HY, ed), pp 359-366. New York: Raven.

Seiden, LS, Fischman MW, Schuster CR (1976) Long-term methamphetamine induced changes in brain catecholamines in tolerant rhesus monkeys. Drug Alcohol Depend 1:215-219.

Sonsalla P, Nicklas W, Heikkila R (1989) Role for excitatory amino acids in methamphetamine-induced nigrostriatal dopaminergic toxicity. Science 243:398-400.

Tedroff J, Aquilonius SM, Hartvig P, Lundquist H, Gee AG, Uhlin J, Langstrom B (1988) Monoamine re-uptake sites in the human brain evaluated in vivo by means of $\left[{ }^{11} \mathrm{C}\right]$ nomifensine and positron emission tomography: the effects of age and Parkinson's disease. Acta Neurol Scand 77:192-201.

Tejani-Butt SM (1992) $\left[{ }^{3} \mathrm{H}\right]$ nisoxetine: a radioligand for quantitation of norepinephrine uptake sites by autoradiography or by homogenate binding. J Pharmacol Exp Ther 260:427-436.

Tetrud JW, Langston JW (1989) The effect of deprenyl selegiline on the natural history of Parkinson's disease. Science 245:519-522.

The Parkinson Study Group (1989) Effect of deprenyl on the progression of disability in early Parkinson's disease. N Engl J Med 321:1364-1371.

The Parkinson Study Group (1993) Effects of tocopherol and deprenyl on the progression in early Parkinson's disease. N Engl J Med 328:176-183.

Vander Borght T, Sima A, Kilbourn M, Desmond T, Kuhl D, Frey K (1996) The vesicular monoamine transporter is not regulated by dopaminergic drug treatments. Eur J Pharmacol 294:577-584.

Wagner GC, Ricaurte GA, Seiden LS, Schuster CR, Miller RJ, Westley J (1980a) Long-lasting depletions of striatal dopamine and loss of dopamine uptake sites following repeated administration of methamphetamine. Brain Res 181:151-160.

Wagner GC, Ricaurte GA, Johansen C, Schuster CR, Seiden LS (1980b) Amphetamine induces caudate dopamine depletions in monkeys. Neurology 30:547-550.

Wagner GC, Preston K, Ricaurte GA, Schuster CR, Seiden LS (1982) Neurochemical similarities between D,L-cathinone and D-amphetamine. Drug Alcohol Depend 9:279-284.

Wilson JM, Kalasinsky KS, Levey AI, Bergeron C, Reiber G, Anthony RM, Schmunk GA, Shannak K, Haycock JW, Kish SJ (1996a) Striatal dopamine nerve terminal markers in human, chronic methamphetamine users. Nature Med 2:699-703.

Wilson JM, Levey AI, Rajput A, Ang L, Guttman M, Shannak K, Niznik H, Hornykiewicz O, Pifl C, Kish SJ (1996b) Differential changes in neurochemical markers of striatal dopamine nerve terminals in idiopathic Parkinson's disease. Neurology 47:718-728.

Wong DF, Yung BCK, Dannals RF, Shaya EK, Ravert HT, Chen CA, Chan B, Folio T, Scheffel U, Ricaurte GA, Neumeyer JL, Wagner Jr HN, Kuhar MJ (1993) In vivo imaging of baboon and human dopamine transporters by positron emission tomography using $\left[{ }^{11} \mathrm{C}\right] \mathrm{WIN}$ 35,428. Synapse 15:130-142.

Wong DF, Harris JC, Naidu S, Yokoi F, Marenco S, Dannals RF, Ravert HT, Yaster M, Evans A, Rousset O, Bryan RN, Gjedde A, Kuhar M, Breese GR (1996) Dopamine transporters are markedly reduced in Lesch-Nyhan disease in vivo. Proc Natl Acad Sci USA 93:5539-5543.

Woolverton WL, Ricaurte GA, Forno LS, Seiden LS (1989) Long-term effects of chronic methamphetamine administration in rhesus monkeys. Brain Res 486:73-78. 